\title{
VÝZNAM ZDIELANIA ZNALOSTÍ PRE ROZVOJ ORGANIZÁCIE
}

\author{
Milan Kubiček*
}

\section{Úvod}

Moderný svet je charakteristický dynamičnost'ou, meniacimi sa trhmi a technickým pokrokom. Na udržanie kroku s týmto trendom musia byt' organizácie čoraz viac flexibilné. Cesta ako to dosiahnut' spočíva vo využití potenciálu učenia celej organizácie. Tieto znalosti sa ukazujú ako hnacia sila a kl'účový faktor vo vytváraní hodnoty. Zvýšený dôraz musí byt' kladený na znalostnú bázu organizácie bud' na základe učenia sa od iných alebo vytváraním nových znalostí prostredníctvom inovácií. Oba procesy pomáhajú bezpečne udržat' konkurenčnú výhodu. Na znalostný manažment možno nazerat' ako na integrujúci prístup, ktorého snahou je dosiahnutie organizačných ciel'ov zameraním sa na znalosti, ktoré sú v širšom chápaní novým výrobným faktorom. Znalostný manažment podporuje a riadi vytváranie, výmenu a aplikáciu individuálnych znalostí prostredníctvom procesu vytvárania hodnoty. To je možné realizovat' iba v podniku s takou podnikovou kultúrou, ktorá podporuje znalostný manažment.

\section{Excelentné organizácie}

Jedným z faktorov, ktoré podporujú inovačné aktivity podniku, je zdiel'anie znalostí medzi zamestnancami. Tomuto zdiel’aniu znalostí napomáha okrem iného aplikácia prvkov tzv. excelentnej spoločnosti. Ked' zvažujeme, či sa nachádzame v excelentnej organizácií, mali by sme sa zamerat' aj na model EFQM.[1]

Tento model predstavuje stále zlepšovanie, nie je statický, lebo sa dokonale prispôsobuje zmenám prostredia. Model EFQM je uznávaným modelom v Európe, je zdokonal'ovaný Európskou nadáciou pre manažérstvo kvality (EFQM) a Európskou organizáciou pre kvalitu (EOQ). EFQM hrá dôležitú úlohu pri zlepšovaní konkurenčného postavenia európskych organizácí́ aj na svetovom trhu.

Dosahuje sa to dvoma spôsobmi:

- prijatím kvality ako stratégie celkového rozvoja a konkurenčnej výhody,

- stimuláciou zamestnancov na zlepšovanie kvality.

Model EFQM poskytuje všeobecné kritéria, ktoré sa dajú použit' v každej organizácií alebo jej časti. Devät' prvkov uvedených v schéme modelu EFQM sú kritéria, podl'a ktorých môžeme hodnotit' výsledky, ktoré organizácia dosiahla v postupe k podnikatel'skej aktivite.[2]

\footnotetext{
* Ing. Milan Kubiček, Žilinská univerzita v Žiline, Fakulta prevádzky a ekonomiky dopravy a spojov, Katedra spojov, Univerzitná 1, 01026 Žilina, tel.: 041/513 3145, e-mail: Milan.Kubicek@fpedas.uniza.sk,
} 
The EFQM Excellence Model

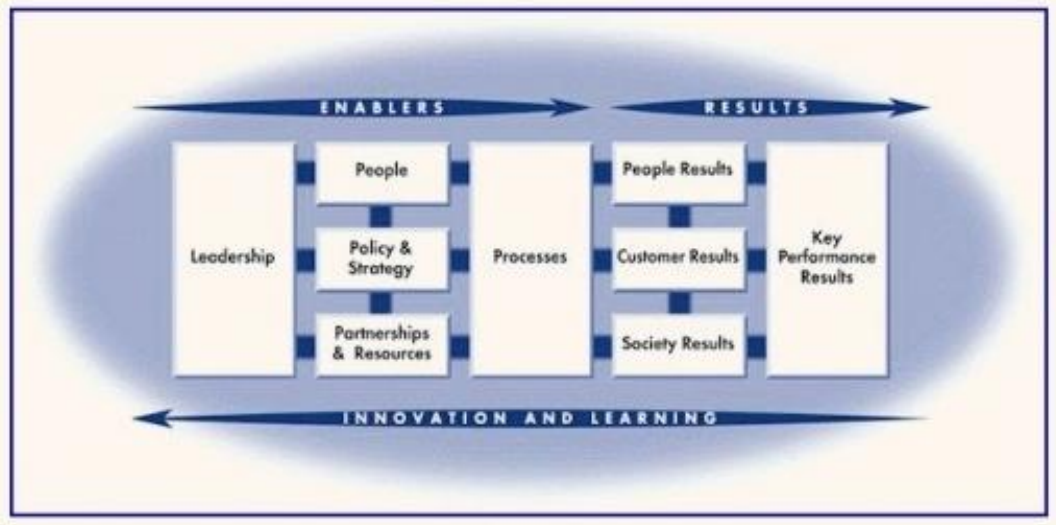

Obr. č. 1: Model výnimočnosti EFQM [3]

1. kritérium: Vodcovstvo - skúma chovanie manažérov a hodnotí úlohu vrcholových manažérov vo vytváraní jasných hodnôt kvality,

2. kritérium: Politika a stratégia - ako organizácia začleňuje svoje ciele a hodnoty kvality do svojej celkovej stratégie a plánovacej činnosti.

3. kritérium: Zamestnanci - ako organizácia využíva plný potenciál svojich zamestnancov. Vyjadruje, ako sú úlohy a ciele zamestnancov prepojené s úlohami a ciel'mi organizácie a či plne rešpektujú pracovné postupy, plány výcviku a hodnotenie výkonu. Skúma, či sa zamestnanci zapájajú do zlepšovania najmä prostredníctvom tímového prístupu $\mathrm{k}$ riešeniu problémov.

4. kritérium: Partnerstvo a zdroje - ako organizácia účinne a efektívne hospodári so zdrojmi, aké metódy a postupy používa pri plánovaní a riadení vonkajších partnerských vzt'ahov i pri riadení vnútorných zdrojov, v záujme podpory svojej politiky a stratégie, i v záujme efektívneho vykonávania procesov.

5. kritérium: Procesy - ako organizácia identifikuje, riadi sleduje a zdokonaluje svoje procesy v záujme napíňania politiky a stratégie i v záujme uspokojovania zákazníkov.

6. kritérium: Výsledky vo vztahu k zamestnancom - čo dosahuje organizácia v súvislosti so spokojnost'ou svojich zamestnancov.

7. kritérium: Výsledky vo vztahu k zákazníkom - čo dosahuje organizácia v súvislosti so spokojnost'ou svojich vonkajších zákazníkov.

8. kritérium: Výsledky vo vzt’ahu kspoločnosti - čo dosahuje organizácia v rámci uspokojovania potrieb a očakávaní miestnej, národnej a medzinárodnej komunity vo vel'kom (podl'a primeranosti), zásada zodpovednosti voči verejnosti. Ide o prístup organizácie ku kvalite života, životnému prostrediu, ochrane globálnych zdrojov a vlastným interným opatreniam organizácie týkajúcim sa efektívnosti. Patria sem vzt’ahy s orgánmi, ktoré majú vplyv na podnik a regulujú jeho činnost'.

9. kritérium: Klúčové výsledky výkonnosti - čo dosiahla organizácia vzhl'adom na plánované podnikatel'ské ciele a na uspokojovanie potrieb a očakávaní všetkých, ktorí majú v organizácii finančný alebo iný záujem. [2] 


\section{Základné členenie znalostí}

Podl'a japonských ekonómov Nonaku a Takeuchiho, ktorí sú považovaní za otcov znalostného manažmentu, sa vedomosti klasifikujú v dvoch rovinách. Explicitné (formálne) môžu byt' vyjadrené $\mathrm{v}$ hmotnej podobe (knihy) a uložené napríklad do podnikového informačného systému.

Rozhodujúci význam však majú vedomosti tacitné (skryté), ktoré sú ukryté v mysli, v správaní sa a v skúsenostiach človeka. Predovšetkým tento typ tacitných vedomostí je kl'účový a tvorí podstatu znalostného manažmentu. Z hl'adiska tacitných vedomostí, ktoré sú podstatné môžeme znalostný manažment označit ako procesný dej produkcie nových vedomostí, v ktorom sa riešia problémy, objavujú zákonitosti, produkujú sa objektívne intelektuálne novosti a inovácie. Znalostný manažment je teda procesom poznávania a pretvárania vedomostí."

Pomer a význam explicitných znalostí ku znalostiam tacitným by sme mohli demonštrovat' nasledovne. Explicitné znalosti predstavujú čast' l'adovca, ktorú je vidno nad morskou hladinou. No tá významnejšia a aj väčšia čast', ktorou sú znalosti tacitné (skryté), nám zostáva ukrytá. [4]

\section{Zdiel’anie znalostí}

V každej organizácií bez ohl’adu na to, či je excelentná alebo nie dochádza $\mathrm{k}$ výmene znalostí (ako tacitných tak aj explicitných). Možné dôvody, pre ktoré dochádza k tejto výmene znalostí by sme mohli definovat' nasledovne:

- reciprocita - pracovník, ktorý disponuje znalost'ou očakáva, že ked' poskytne svoju znalost', dostane za ňu v budúcnosti inú znalost',

- reputácia - pracovník si poskytnutím znalosti zlepší svoju image,

- altruizmus - pracovníkovi obvykle nejde o odmenu, ale o rozšírenie znalostí.

V každej organizácií existuje tiež neformálna znalostná siet'. Pri jej tvorbe majú vel'ký význam osobné kontakty a drobná každodenná konverzácia. Pochopenie a uvedomelé riadenie znalostí v organizácií môže zlepšit' prácu organizácie zo znalost’ami a tým aj jej celkové výkony. Zvyšuje mimo iné inovačnú kapacitu firmy, pomáha rozvoju schopností pracovníkov, znižuje náklady (napr. vd'aka tomu, že sú medzi pracovníkmi odovzdávané vhodné postupy, či už prostredníctvom rád alebo doporučení.

Pretože organizácie nedostatočne oceňujú pracovníkov, ktorý sa snažia svoje znalosti odovzdávat' a zdiel'at' dochádza k tomu, že jedinec alebo skupina pracovníkov radšej znalosti zadržuje takže sa d’alej nerozširujú, aj ked' ich iný potrebujú ku svojej práci. [1]

Všeobecne by sme ale mohli bariéry brániace šíreniu informácií zhrnút’ nasledovne:

1.) Individuálne bariéry:

- Pocit nedostatku moci - poskytnutím znalosti kolegovi sa stráca exkluzivita vplyvu, ktorý môže zaist'ovat' určitú istotu práce alebo rešpekt. Platí staré známe „znalost’ je moc“, kto ju nemá nenájde v organizácii uplatnenie.

○ Strach zodhalenia, že moje znalosti nie sú na dostatočnej úrovni poskytnutím znalosti sa dáva najavo, že táto znalost' má istú hodnotu 
a vzácnost'. Pokial' toto hodnotenie nie je zdiel'ané ostatnými používatel'mi bázy poznatkov, má človek trápny pocit.

- Pocit neistoty - špeciálne mladší a menej skúsení zamestnanci môžu cítit' určitú neistotu, pretože nedokážu ohodnotit', či výsledky ich práce predstavujú hodnotnú znalost' pre ostatných. Nemôžu odhadnút', či je ich znalost' príliš všeobecná alebo už dobre známa, alebo či nie sú niektoré výsledky príliš špecifické pre určitú situáciu, a preto nepoužitel'né ostatnými spolupracovníkmi v iných situáciách.

- Motivácia - zdiel'anie znalostí sa môže chápat' ako práca navyše, pretože je na to potrebný čas na dokumentáciu, komunikáciu, apod. Niektorí zamestnanci za to môžu očakávat' „niečo“ navyše. Vhodná forma motivácie zdiel'ania znalostí je však vel'mi užitočná.

- Ilúzia straty odmeny - niektorí pracovníci vidia v zdiel'aní znalostí spôsob, akým môžu príst' o odmenu za svoju prácu, ked’že svoje znalosti a skúsenosti odovzdajú niekomu inému a on na ich základe vykoná prácu, za ktorú dostane mzdu či akúkol'vek inú odmenu.

○ Neuvedomovanie si jednotlivých prvkov kultúry - zamestnanci majú často problém konkrétne pomenovat' základné firemné hodnoty, potreby, ale aj ciele, aj ked' inak o organizácií vel'a vedia.

○ Zámena povedomia za znalost' - niektorí pracovníci majú iba isté povedomie o probléme, nie však znalost'. To zapríčiňuje, že nechcú „počut' zasa to isté, o čom už vedia“.

○ Konflikt motívov - rozhodovanie sa medzi dvoma alebo viacerými tendenciami, pričom tieto môžu byt' rovnako silné, ale trebárs aj protikladné.

2.) Sociálne bariéry:

○ Jazyk - v niektorých organizáciách sa jazyk používa v jednej ich časti, úseku, oddelení, často nezrozumitel'ný pre ostatných. Preto je potrebné dodržiavat' zásady jednotného jazyka, alebo používanie vhodného opisu, analógie, metafor. Jednotlivci tak môžu lepšie pochopit' aj skryté (tacitné) znalosti, mentálne modely, názory iných a pod.

○ Vyhýbanie sa konfliktu - ak je v organizácii snaha vyhýbat' sa zmenám a príliš neriskovat', môžu sa nové znalosti a prístupy obsahujúce nové myšlienky alebo inovatívne názory postupne stratit'.

- Byrokracia a štruktúra - vel'mi byrokratické a administratívne organizácie používajú pracovné postupy a procedúry, ktoré bránia zdiel'aniu znalostí. napr.: silne štruktúrovaná organizácia neumožňuje diagonálnu komunikáciu, kooperáciu alebo práve zdiel’anie znalostí. 
- Nesúvislost' predpokladov - nedostatok súvislosti medzi osobnými postojmi a predpokladmi organizácie (vízia, hodnoty, strategický smer a pod.) spôsobuje zložitost' vo vyjadrovaní a ospravedlňovaní osobných názorov, ktoré nie sú zlučitel'né s predpokladmi organizácie. Neistota zapríčinená nedostatočnou komunikáciou o budúcej vízii, postavení organizácie alebo o hlavných strategických úlohách môže spôsobovat' nedostatočné vyjadrovanie myšlienok a znalostí.

○ Podceňovanie najnižších vrstiev - vrcholové vedenie organizácie väčšinou zastáva „tradičnýc manažment znalostí, ktorý ukladá informácie z minulosti s predpokladom, že potreba budúcich informácií bude rovnaká. Tento prístup považuje znalostných pracovníkov za pasívnych príjemcov informácií a znalostí. Vedenie organizácie zbiera a štrukturalizuje obsah organizačnej pamäti akoby išlo o hotový produkt $\mathrm{v}$ čase návrhu a potom ju v podniku rozširuje. Ide tu o prístup ,zhora nadol“, kde vedenie vytvára znalosti a pracovníci ich prijímajú. „Tvorivý prístup“ $\mathrm{k}$ manažmentu znalostí vychádza z predpokladu, že znalostní pracovníci, konštantne tvoria nové znalosti počas svojej práce. Tento prístup považuje pracovníkov za premýšl’avých odborníkov, ktorí každý deň pri svojej práci riešia nedefinované problémy a zápasia s nimi. Dôležité sú tu dva aspekty. Po prvé pracovníci, a nie manažéri, tvoria znalosti v pracovnom čase a počas ich používania. Po druhé, znalost' je vedl'ajší produkt práce.

○ Neznalost' alebo chybný odhad znalostí spolupracovníka - pri zdiel'aní znalostí hrá vel'mi dôležitú úlohu komunikácia. Dôležitý je tu prevod myšlienky do jazyka zrozumitel'ného príjemcovi. Ak nie je odosielatel' schopný odhadnút' stav a vel'kost' bázy znalostí príjemcu, nemusí byt' zdiel'anie znalostí prínosné, i ked' proces komunikácie prebehne.

- Emócie - emócie majú vplyv na samotnú ochotu zamestnanca s niekým znalosti zdiel'at'. Ak panuje nevraživý a nepriatel'ský vzt'ah medzi dvoma zamestnancami, nie je jednoduché ich primät', aby znalosti zdiel'ali.

○ Pseudoinovátori - l'udia, ktorí rýchle vyzdvihujú svoje návrhy a „,nevyhnutné“ úpravy myšlienok, poznatkov alebo návrhov ostatných tak, aby zdôraznili svoju vlastnú dôležitost', čo niektorí pôvodní autori pocit'ujú ako znižovanie ich postavenia. [45]

\section{Záver}

V našich podmienkach je význam zdiel'ania znalostí stále podceňovaný. Firmy nemajú vedomie o prínose pri uplatňovaní EFQM nieto ešte o nutnosti a nevyhnutnosti zdiel'ania znalostí. Organizácie si stále neuvedomujú ako je zdiel'anie znalostí dôležité a potrebné. Neuvedomujú si, že je to cesta zvýšenia ich konkurencieschopnosti. 


\section{Literatúra:}

[1] MATOŠKOVÁ, J., VOLOCH, J. Význam sdílení znalostí pro inovační rozvoj firmy. In Sborník př́spěvků z mezinárodní vědecké konference Podmínky podnikatelské úspěšnosti inovací konané 3. 11. 2006 v Praze. 1. vyd. Praha: Soukromá vysoká škola ekonomických studií, 2006. CD-ROM. ISBN 978-80-86744-57-5.

[2] ŠTOFKOVÁ, J.a kol.: Manažment podniku, vydavatel'stvo EDIS, 2008, ISBN 9788070-713-2

[3] pdca.wordpress.com

[4] BUREŠ, V.: Znalostní management a proces jeho zavádění, Grada, Praha 2007, ISBN 978-80-247-1978-8

[5] KELEMEN, J. a kol.: Pozvanie do znalostnej spoločnosti, Lura Edition, Bratislava 2007, ISBN 978-80-8078-149-1

[6] BRABECK, R., ŠTOFKOVÁ, K.: Strategisches Management im postindustriellen Zeitalter $=$ Wissensmanagement durch Information und Komunikation. In: Pošta, telekomunikácie a elektronický obchod III/2007, Žilinská univerzita v Žiline. ISSN 1336-8281

[7] ŠTOFKOVÁ, J., ŠTOFKOVÁ, K.: Využitie metódy BSC v riadení podniku. In: Diagnostika podniku, controlling a logistika IV. medzinárodná vedecká konferencia. Žilinská univerzita, 2008. ISBN 978-80-8070-819-1

\section{Grantová podpora}

Príspevok je publikovaný v rámci projektu VEGA 2009-2011 „Metódy a techniky strategického manažmentu ako nástroj zvyšovania efektívnosti podniku- č. 1/0757/09, Žilinská univerzita v Žiline 